\title{
Effect of Gamma Irradiation, Packaging and Storage on Vitamin C Content of Garden Eggs
}

\author{
Abraham Adu-Gyamfi ${ }^{1}$, Nkansah Minnoh Riverson ${ }^{2}$, Nusrut Afful ${ }^{3}$, Victoria Appiah ${ }^{2}$ \\ ${ }^{1}$ Radiation Technology Centre, Biotechnology and Nuclear Agriculture Research Institute, Ghana Atomic Energy Commission, Accra, Ghana \\ ${ }^{2}$ Department of Nuclear Agriculture and Radiation Processing, School of Nuclear and Allied Sciences, University of Ghana, Accra, Ghana \\ ${ }^{3}$ Biotechnology Centre, Biotechnology and Nuclear Agriculture Research Institute, Ghana Atomic Energy Commission, Accra, Ghana
}

Email address:

adugyamfi21@yahoo.com (A. Adu-Gyamfi), riversongh@gmail.com (N. M. Riverson), vicapiah@yahoo.com (V. Appiah), enusrat@yahoo.com (N. Afful)

To cite this article:

Abraham Adu-Gyamfi, Nkansah Minnoh Riverson, Nusrut Afful, Victoria Appiah. Effect of gamma irradiation, packaging and storage on vitamin C content of garden eggs, International Journal of Nutrition and Food Sciences. Vol. 5, No. 5, 2016, pp. 367-371. doi: $10.11648 /$ j.ijnfs.20160505.18

Received: August 25, 2016; Accepted: September 2, 2016; Published: October 17, 2016

\begin{abstract}
Garden eggs are important economic vegetable crops which serve as excellent source of food with high Vitamin C content. The effect of gamma radiation $(0,1,2,3 \mathrm{kGy})$, packaging (polyethylene) and storage $\left(0,1,2,3,4\right.$ weeks at $\left.29 \pm 1^{\circ} \mathrm{C}\right)$ on the Vitamin C content of three varieties of garden eggs (Solanum aethiopicum GH 8772 and Solanum aethiopicum GH 8773, and Solanum torvum) were studied. Irradiation was done using a cobalt-60 source and the Vitamin C content of the samples were determined by the method of Ciancaglini et al (2001). The effect of gamma irradiation ( 1 - $3 \mathrm{kGy}$ ) on Vitamin C content of the three varieties of garden eggs was not uniform. Packaging with polythene decreased the content of Vitamin C in fruits of Solanum torvum but not those of Solanum aethiopicum L. [GH 8772 and GH 8773]. Storage period decreased the Vitamin C content of packaged samples of all three varieties of garden eggs.
\end{abstract}

Keywords: Gamma Irradiation, Vitamin C, Packaging, Storage, Garden Eggs

\section{Introduction}

Garden eggs (Solanum spp.) is a woody perennial herb of the Family Solanaceae. Consumption of its fruits is widespread in the tropics and temperate parts of the world [1] When matured, fruits may be eaten raw or boiled, fried and sautéed for soup and stew $[2,3]$. The fruits are used as food in addition to serving as rich sources of vitamins A, B and C, potassium, magnesium, calcium, phosphorus and sodium. These vitamins and minerals are useful for the prevention or treatment of diseases such as asthma, bronchitis, cholera and dysuria [1, 4]. [5] reported that extracts from garden egg suppress the development of blood vessels required for tumor growth and metastasis, and also inhibit protein-activated receptor 2 inflammation that causes atherosclerosis [6].

Garden egg was ranked in the top 10 species for superoxide scavenging (SOS) activity [7] of 120 vegetables species evaluated for antioxidant activity using four different assays (2,2'-azino-bis-3-ethylbenzthiazoline-6-sulphonic acid
[ABTS], 2, 2-diphenyl-1-picrylhydrazyl radical [DPPH], inhibition of lipid peroxidation [ILP], and superoxide scavenging $[\mathrm{SOS}]$ ). Antioxidant activity has been linked to ascorbic acid and high phenolic content in the leaves, calyx and fleshy portions of the fruit $[8,9,10]$.

Garden eggs have limited shelf-life for freshness mainly due to their high evapo-transpiration rate resulting in rapid water loss. Poor post-harvest handling, shoot and fruit borers, and the lack of quality standards contribute greatly to yield losses in Ghana. In addition, garden egg plants are also prone to infection by pests, fungi, bacteria and viruses at all stages of growth on field and after harvest [11].

In spite of the beneficial uses of garden eggs, research into extending the shelf-life of garden eggs using gamma irradiation has received little attention in most developing countries. Refrigeration, modified atmosphere storage, freezing and drying represent some of the technologies utilized in shelf-life extension of garden eggs [12, 13, 14, 15]. Irradiation is a proven technology which has been endorsed by notable international health and food authorities. As a 
process it has the capacity to eliminate insect pests and microbial pathogens from fresh fruits and vegetables. It also delays ripening and senescence thereby extending the shelf life of fresh fruits and vegetables without adverse effect on the quality [16].

Phytosanitary doses of irradiation ( 0.15 to $1 \mathrm{kGy})$ in general have no effect on macronutrients or minerals in fruits and vegetables $[17,18]$. There is medium to high sensitivity of Vitamin C to irradiation in most fresh produce [19]. Most vegetables continue to ripen after harvest and therefore post harvest handling and storage can also affect nutrient composition of vegetable vitamin levels [20, 21]. Although packaging protects fresh produce from mechanical damage and poor environmental conditions, information on its impact on nutrients is very limited. Therefore the objective of this study was to determine the effect of gamma radiation, packaging and storage on the Vitamin $\mathrm{C}$ content of three varieties of garden eggs (Solanum aethiopicum L. [GH 8772 and GH 8773] and S. torvum).

\section{Materials and Methods}

\subsection{Sampling}

Three varieties of garden eggs (Solanum aethiopicum GH 8772; GH8773 and S. torvum) were obtained from a market in Accra, Ghana. The samples were obtained 2 days after harvest and sorted to remove bruised, pitted, riped fruits as well as fruits without stalk (calyx). For the purpose of easy referencing, fruits of GH8772 and GH8773 were coded "A" and " $C$ " whiles those of $S$. torvum were coded "B".

\subsection{Packaging of Samples}

The fruits were surface-sterilised with $70 \%$ alcohol. Packaging was done by placing 10 fruits (approximately 400 $500 \mathrm{~g}$ of $\mathrm{A}$ and $\mathrm{C}$ ) and $300 \mathrm{~g}$ of B in perforated polyethylene zip - lock pouches $($ density $=0.18 \mathrm{~g} / \mathrm{cm} 3)$.

\subsection{Irradiation of Samples}

The samples were irradiated under ambient conditions using a Cobalt-60 source at the Gamma Irradiation Facility (GIF) of the Radiation Technology Centre (RTC) in Ghana Atomic Energy Commission (GAEC) at doses of 0, 1, 2 and 3 $\mathrm{kGy}$. The dose rate during the irradiation process was 1.962 $\mathrm{kGy} / \mathrm{hr}$ and ferrous sulphate (Fricke) dosimeter was used to measure absorbed dose.

\subsection{Storage of Samples}

The packaged sample (perforated zip - lock pouches) and the unpackaged control sample were stored at $29 \pm 1{ }^{\circ} \mathrm{C}$ under two packaging conditions.

\subsection{Determination of Vitamin C content}

The ascorbic acid content in the samples was determined by the method outlined by [22]. A $0.005 \mathrm{M}$ of iodine solution was prepared by weighing $2 \mathrm{~g}$ of potassium iodide and $1.3 \mathrm{~g}$ of iodine into a beaker. Few drops of distilled water were added and swirled until all the iodine had dissolved. The solution formed was made up to 1 litre in a volumetric flask. Fruits (two fruits per variety, dose and package) were picked at random from the lot, chopped into pieces and $10 \mathrm{~g}$ of the samples were taken and homogenized with a laboratory Waring blender. The slurry was put into Eppendorf centrifuge tubes. They were centrifuged using Extra Merlin 505 Centrifuge (UK). Twenty millilitres of the supernatant was poured into a $250 \mathrm{ml}$ conical flask. The iodine solution was titrated against the supernatant. $1 \%(\mathrm{w} / \mathrm{v})$ starch solution prepared by weighing $1 \mathrm{~g}$ of powdered starch and dissolving it in $100 \mathrm{ml}$ of distilled water served as an indicator. One millilitre of starch solution indicator was added to the supernatant of the homogenized pulp to serve as an indicator to a blue-black colour end point. The titration was done in triplicate at the Physicochemical Laboratory of RTC, GAEC. The titre values were used to calculate the ascorbic acid content of the fruits.

\subsection{Statistical Analysis}

The results obtained from the experiments were analyzed using Statgraphics Centurion software (XVI.I edition). One-way and two-way analyses of variance were used to determine significant differences at $95 \%$ confidence interval.

\section{Results}

\subsection{Effect of Irradiation on Vitamin C Content of Garden Eggs}

As shown in Tables 1 and 3 , significant differences $(\mathrm{P}<0.05)$ were observed in the effect of gamma irradiation on the Vitamin $\mathrm{C}$ content of the three varieties of garden eggs. Whiles irradiation dose of $3 \mathrm{kGy}$ reduced the Vitamin $\mathrm{C}$ content of samples of Variety $\mathrm{B}$ and the packaged samples of Varieties $\mathrm{A}$ and $\mathrm{C}$, it increased the Vitamin $\mathrm{C}$ content of unpackaged samples of Variety A and C. However, doses of 1 and $2 \mathrm{kGy}$ decreased the Vitamin $\mathrm{C}$ content in varieties $\mathrm{A}$ and $\mathrm{B}$ but increased that of Variety $\mathrm{C}$.

\subsection{Effect of Packaging on Vitamin C Content of Garden Eggs}

Figure 1 shows the effect of packaging on the Vitamin $\mathrm{C}$ content of the three varieties of garden eggs. There were significant differences $(\mathrm{P}<0.05)$ between the packaged and unpackaged samples of Variety B but not those of samples A and C. Among both the packaged and unpackaged samples, Variety B had significantly higher Vitamin C content compared to Varieties A and C.

\subsection{Effect of Storage on Vitamin C Content of Garden Eggs}

There were significant differences $(\mathrm{P}<0.05)$ within the samples of all three varieties during the storage period with respect to their Vitamin $\mathrm{C}$ content (Table 2). As storage period progressed, there were decreases in Vitamin $\mathrm{C}$ content 
for the packaged samples of all three varieties compared to unpackaged samples. In the case of unpackaged samples of Variety B, there was a clear pattern of decline in Vitamin C content as storage period progressed.

Table 1. Effect of irradiation on the vitamin $C$ content of three varieties of garden eggs stored under two packaging conditions.

\begin{tabular}{lllllll}
\hline \multicolumn{6}{c}{ Varieties } \\
\hline \multicolumn{5}{c}{ S. aethiopicum - $[\mathrm{A}]$} & S. torvum - [B] & S. aethiopicum - $[\mathrm{C}]$ \\
\hline Dose (kGy) Unpack & Pack & Unpack & Pack & Unpack & Pack \\
\hline 0 & $1.43^{\mathrm{a}}$ & $1.34^{\mathrm{a}}$ & $23.82^{\mathrm{b}}$ & $8.19^{\mathrm{b}}$ & $1.78^{\mathrm{a}}$ & $1.23^{\mathrm{b}}$ \\
1 & $2.05^{\mathrm{bc}}$ & $1.23^{\mathrm{a}}$ & $13.65^{\mathrm{ab}}$ & $2.73^{\mathrm{a}}$ & $2.05^{\mathrm{ab}}$ & $1.41^{\mathrm{b}}$ \\
2 & $2.28^{\mathrm{c}}$ & $0.82^{\mathrm{a}}$ & $13.65^{\mathrm{ab}}$ & $2.73^{\mathrm{a}}$ & $2.23^{\mathrm{b}}$ & $1.50^{\mathrm{b}}$ \\
3 & $1.68^{\mathrm{ab}}$ & $0.96^{\mathrm{a}}$ & $8.19^{\mathrm{a}}$ & $2.73^{\mathrm{a}}$ & $2.05^{\mathrm{ab}}$ & $0.73^{\mathrm{a}}$ \\
\hline
\end{tabular}

Values are means of 15 determinations - (3 replicates by 5 storage weeks) Mean values in the same column with different letters $(a-c)$ were significantly different $(P<0.05)$; Vitamin C content in $\mathrm{mg} / 100 \mathrm{~g}$

Table 2. Effect of storage on the vitamin C content of three varieties of garden eggs stored under two packaging conditions.

\begin{tabular}{|c|c|c|c|c|c|c|}
\hline \multicolumn{7}{|c|}{ Varieties } \\
\hline & \multicolumn{6}{|c|}{ S. aethiopicum $-[\mathrm{A}]$ S. torvum $-[\mathrm{B}]$ S. aethiopicum $-[\mathrm{C}]$} \\
\hline Storage & Week Unpack & Pack & Unpack & x Pack & Unpack & Pack \\
\hline 0 & $1.08^{\mathrm{a}}$ & $1.71^{\mathrm{d}}$ & $37.54^{\mathrm{c}}$ & $13.65^{\mathrm{c}}$ & $1.25^{\mathrm{a}}$ & $1.54^{\mathrm{bc}}$ \\
\hline 1 & $2.62^{\mathrm{c}}$ & $1.48^{\mathrm{cd}}$ & $23.89^{\mathrm{b}}$ & $3.41^{\mathrm{b}}$ & $2.28^{\mathrm{ab}}$ & $1.08^{\mathrm{ab}}$ \\
\hline 2 & $1.54^{\mathrm{b}}$ & $1.00^{\mathrm{bc}}$ & $5.69^{\mathrm{a}}$ & $0.00^{\mathrm{a}}$ & $2.05^{\mathrm{b}}$ & $1.02^{\mathrm{a}}$ \\
\hline 3 & $1.76^{\mathrm{b}}$ & $0.91^{\mathrm{b}}$ & $6.83^{\mathrm{a}}$ & $3.41^{\mathrm{b}}$ & $2.16^{\mathrm{ab}}$ & $1.59^{\mathrm{c}}$ \\
\hline
\end{tabular}

\begin{tabular}{lllllll}
\hline \multicolumn{6}{c}{ Varieties } \\
\hline \multicolumn{4}{c}{ S. aethiopicum - $[\mathrm{A}]$} & S. torvum $-[\mathrm{B}]$ & S. aethiopicum $-[\mathrm{C}]$ \\
\hline Storage Week Unpack & Pack & Unpack Pack & Unpack & Pack \\
\hline 4 & $2.30^{\mathrm{c}}$ & $0.34^{\mathrm{a}}$ & $0.20^{\mathrm{a}}$ & $0.00^{\mathrm{a}}$ & $2.39^{\mathrm{b}}$ & $0.85^{\mathrm{a}}$ \\
\hline
\end{tabular}

Values are means of 12 determinations - ( 3 replicates by 4 storage weeks)Mean values in the same column with different letters $(\mathrm{a}-\mathrm{d})$ were significantly different $(\mathrm{P}<0.05)$; Vitamin $\mathrm{C}$ content in $\mathrm{mg} / 100 \mathrm{~g}$

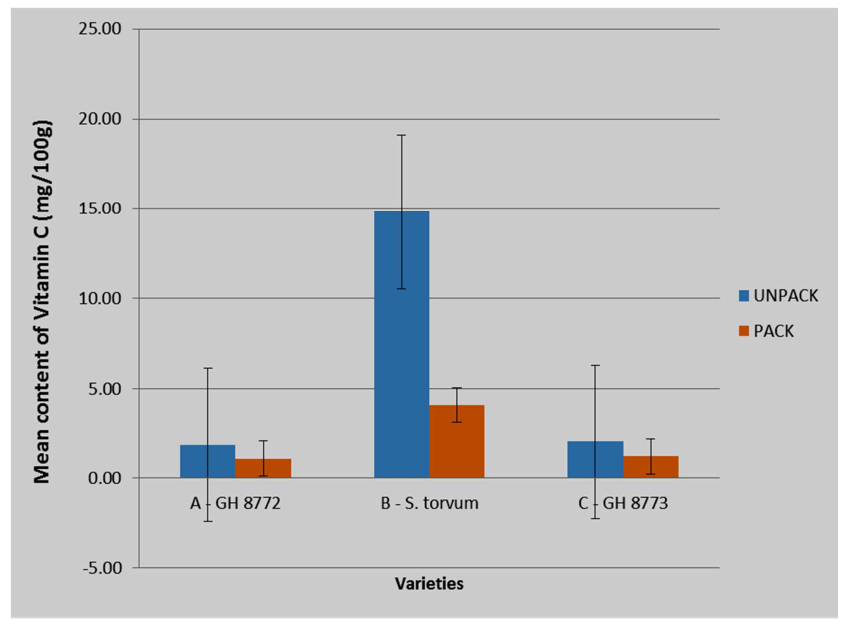

Figure 1. Effect of two packaging conditions on the population of aerobic mesophiles for three varieties of garden eggs.

Table 3. Interactive effect of irradiation and storage on Vitamin C content of three varieties of garden eggs under two packaging conditions at room temperature.

\begin{tabular}{|c|c|c|c|c|c|c|c|}
\hline \multirow[b]{3}{*}{ Dose (kGy) } & \multirow[b]{3}{*}{ Storage Week } & \multicolumn{6}{|c|}{ Varieties } \\
\hline & & \multicolumn{2}{|c|}{ S. aethiopicum - [A] } & \multicolumn{2}{|c|}{ S. torvum $-[\mathrm{B}]$} & \multicolumn{2}{|c|}{ S. aethiopicum - [C] } \\
\hline & & Unpack & Pack & Unpack & Pack & Unpack & Pack \\
\hline \multirow[t]{5}{*}{ - } & 0 & $0.68^{\mathrm{c}}{ }_{\mathrm{A}}$ & $2.05^{\mathrm{w}}{ }_{\mathrm{K}}$ & $27.30^{\mathrm{b}}{ }_{\mathrm{B}}$ & $13.65^{z}{ }_{L}$ & $1.37_{\mathrm{A}}^{\mathrm{ab}}$ & $2.05^{\mathrm{w}}{ }_{\mathrm{K}}$ \\
\hline & 1 & $2.05_{\mathrm{A}}^{\mathrm{abc}}$ & $1.37^{\mathrm{y}}{ }_{\mathrm{K}}$ & $40.96^{\mathrm{a}}{ }_{\mathrm{C}}$ & $13.65^{\mathrm{z}}{ }_{\mathrm{L}}$ & $2.28^{\mathrm{ab}}{ }_{\mathrm{A}}$ & $1.37^{\mathrm{x}}{ }_{\mathrm{K}}$ \\
\hline & 2 & $1.37_{\mathrm{A}}^{\mathrm{bc}}$ & $1.25^{\mathrm{yz}} \mathrm{K}$ & $22.75^{\mathrm{c}}{ }_{\mathrm{B}}$ & - & $1.37_{\mathrm{A}}^{\mathrm{ab}}$ & $1.37^{\mathrm{x}}{ }_{\mathrm{K}}$ \\
\hline & 3 & $1.37^{\mathrm{bc}}{ }_{\mathrm{A}}^{\mathrm{n}}$ & $2.05^{\mathrm{w}}{ }_{\mathrm{K}}$ & $27.30^{\mathrm{b}}{ }_{\mathrm{B}}$ & $13.65^{\mathrm{z}}{ }_{\mathrm{L}}$ & $1.82^{\mathrm{ab}}{ }_{\mathrm{A}}^{\mathrm{A}}$ & $1.37^{\mathrm{x}}{ }_{\mathrm{K}}$ \\
\hline & 4 & $1.71_{\mathrm{A}}^{\mathrm{bc}}$ & - & $0.80^{\mathrm{d}}{ }_{\mathrm{A}}$ & - & $2.05^{\mathrm{ab}}{ }_{\mathrm{A}}$ & - \\
\hline \multirow{5}{*}{1} & 0 & $1.37_{\mathrm{A}}^{\mathrm{a}}$ & $2.05^{\mathrm{w}}{ }_{\mathrm{K}}$ & $40.96^{\mathrm{a}}{ }_{C}$ & $13.65^{\mathrm{z}}{ }_{\mathrm{L}}$ & $0.68_{\mathrm{A}}^{\mathrm{b}}$ & $1.37^{\mathrm{x}}{ }_{\mathrm{K}}$ \\
\hline & 1 & $2.73^{\mathrm{a}}{ }_{\mathrm{A}}$ & $1.14^{\mathrm{z}}{ }_{\mathrm{K}}$ & $27.30^{\mathrm{b}}{ }_{\mathrm{B}}$ & - & $2.05^{\mathrm{ab}}{ }_{\mathrm{A}}$ & $1.37^{\mathrm{x}}{ }_{\mathrm{K}}$ \\
\hline & 2 & $1.37^{\mathrm{bc}}{ }_{\mathrm{A}}$ & - & - & - & $2.73^{\mathrm{a}}{ }_{\mathrm{A}}$ & $0.68^{\mathrm{z}}{ }_{\mathrm{K}}$ \\
\hline & 3 & $2.05^{\mathrm{abc}}{ }_{\mathrm{A}}$ & $1.59^{\mathrm{x}}{ }_{\mathrm{K}}$ & - & - & $2.05^{\mathrm{ab}}{ }_{\mathrm{A}}$ & $2.28^{\mathrm{v}} \mathrm{K}$ \\
\hline & 4 & $2.73^{\mathrm{a}}{ }_{\mathrm{A}}$ & $1.37^{\mathrm{y}}{ }_{\mathrm{K}}$ & - & - & $2.73^{\mathrm{a}}{ }_{\mathrm{A}}$ & $1.37^{\mathrm{x}}{ }_{\mathrm{K}}$ \\
\hline \multirow{5}{*}{2} & 0 & $0.91_{\mathrm{A}}^{\mathrm{c}}$ & $1.37^{\mathrm{y}} \mathrm{K}$ & $40.96^{\mathrm{a}} \mathrm{C}$ & $13.65^{z}{ }_{L}$ & $1.59^{\mathrm{ab}} \mathrm{A}$ & $1.37^{\mathrm{x}}{ }_{\mathrm{K}}$ \\
\hline & 1 & $3.64^{\mathrm{a}}{ }_{\mathrm{A}}$ & $1.37^{\mathrm{y}} \mathrm{K}$ & $27.30^{\mathrm{b}}{ }_{\mathrm{B}}$ & - & $2.05^{\mathrm{ab}}{ }_{\mathrm{A}}$ & $0.68^{\mathrm{z}}{ }_{\mathrm{K}}$ \\
\hline & 2 & $2.05^{\mathrm{a}} \mathrm{A}$ & $1.37^{\mathrm{y}} \mathrm{K}$ & - & - & $2.05^{\mathrm{ab}}{ }_{\mathrm{A}}$ & $2.05^{\mathrm{w}}{ }_{\mathrm{K}}$ \\
\hline & 3 & $2.05^{\mathrm{abc}}{ }_{\mathrm{A}}$ & - & - & - & $2.73^{\mathrm{a}}{ }_{\mathrm{A}}$ & $1.37^{\mathrm{x}}{ }_{\mathrm{K}}$ \\
\hline & 4 & $2.73^{\mathrm{a}}{ }_{\mathrm{A}}$ & - & - & - & $2.73^{\mathrm{a}}{ }_{\mathrm{A}}$ & $2.05^{\mathrm{w}}{ }_{\mathrm{K}}$ \\
\hline \multirow{5}{*}{3} & 0 & $1.37^{\mathrm{bc}} \mathrm{A}$ & $1.37^{\mathrm{y}} \mathrm{K}$ & $40.96^{\mathrm{a}}{ }_{\mathrm{C}}$ & $13.65^{z}$ & $1.37^{\mathrm{ab}} \mathrm{A}$ & $1.37^{\mathrm{x}}{ }_{\mathrm{K}}$ \\
\hline & 1 & $2.05^{\mathrm{abc}}{ }_{\mathrm{A}}^{\mathrm{A}}$ & $2.05^{\mathrm{w}}{ }_{\mathrm{K}}$ & - & - & $2.73^{\mathrm{a}}{ }_{\mathrm{A}}^{\mathrm{A}}$ & $0.91^{\mathrm{y}}{ }_{\mathrm{K}}$ \\
\hline & 2 & $1.37^{\mathrm{bc}}{ }_{\mathrm{A}}$ & $1.37^{\mathrm{y}}{ }_{\mathrm{K}}$ & - & - & $2.05^{\mathrm{ab}}{ }_{\mathrm{A}}$ & - \\
\hline & 3 & $1.59^{\mathrm{bc}}{ }_{\mathrm{A}}$ & - & - & - & $2.05^{\mathrm{ab}}{ }_{\mathrm{A}}$ & $1.37^{\mathrm{x}}{ }_{\mathrm{K}}$ \\
\hline & 4 & $2.05^{\mathrm{abc}}{ }_{\mathrm{A}}$ & - & - & - & $2.05^{\mathrm{ab}}{ }_{\mathrm{A}}$ & - \\
\hline
\end{tabular}

Values are means of 3 determinations, Vitamin C content in $\mathrm{mg} / 100 \mathrm{~g} ;-=$ no data due to spoilage a-d (unpack), w- $\mathrm{z}$ (pack) $=$ Mean values in the same column with different letters were significantly different $(P<0.05)$ A-C (unpack), K-M (pack) = Mean values in the same row with different letters were significantly different $(P<0.05) \mathrm{A}=$ Solanum aethiopicum $(\mathrm{GH} 8772) \mathrm{B}=$ Solanum torvum $\mathrm{C}=$ Solanum aethiopicum $(\mathrm{GH} 8773)$

\section{Discussion}

\subsection{Effect of Irradiation on Vitamin C Content of Garden Eggs}

Vitamin $\mathrm{C}$ is a water-soluble vitamin which is inherently unstable in solution with its destruction affected by temperature, light and $\mathrm{pH}$ [23]. As a result of this observation, Vitamin $\mathrm{C}$ has been identified as one of the most sensitive vitamins to irradiation, with the effect of irradiation influenced by exposure to oxygen, storage and temperature as well as the $\mathrm{pH}$ of the food matrix or storage medium [19]. 
The effect of radiation dose on the Vitamin $\mathrm{C}$ content of varieties $\mathrm{A}$ and $\mathrm{C}$ did not follow a clear pattern (Tables 1 and 3 ). This observation might be due to differences in maturity of the samples within each variety in this study. Samples of variety B had the highest Vitamin C content (14.83 mg/100g) among the three varieties of garden eggs. According to a study by [24], irradiation can reduce Vitamin C content in some vegetables but the decrease is inconsequential and does not exceed the decline seen during storage. Other studies have shown radiation dose of $1 \mathrm{kGy}$ significantly reduced Vitamin $\mathrm{C}$ levels in fresh-cut lettuce [25] and $3 \mathrm{kGy}$ also led to $20.4 \%$ loss in tomatoes [26]. In this study also, the Vitamin C content of samples of variety B decreased after irradiation. Minimal changes were also observed in Vitamin $\mathrm{C}$ levels in capsicums irradiated with 1, 2 and $3 \mathrm{kGy}$ [27]. In some curcubit vegetables (cucumber, carrot), irradiation with dose up to 2 kGy did not significantly affect Vitamin C levels [28].

\subsection{Effect of Packaging on Vitamin C Content of Garden Eggs}

In this study, samples of garden eggs under packaged condition (polythene) of storage had significantly lower Vitamin C content for variety B compared to samples under unpackaged condition of storage. In the case of varieties $\mathrm{A}$ and $\mathrm{C}$, the differences between package and unpackaged samples were not significant. In a related study, garden eggs stored in a perforated plastic container had higher Vitamin C content compared to those stored in sisal sack and a passive evaporative cooler [29]. However, there was no difference in loss of Vitamin $\mathrm{C}$ of ready-to-use broccoli and green pepper under different packaging systems [30]. The reduction in Vitamin $\mathrm{C}$ content of samples under packaged storage conditions might be due to a build-up of heat as a result of respiration. Vitamin $\mathrm{C}$ has been shown to be unstable at high temperatures [29, 31].

\subsection{Effect of Storage on Vitamin C Content of Garden Eggs}

Vitamin $\mathrm{C}$ has been shown to be unstable during storage at room temperature because of oxidation [32]. This might explain the results of this study which have revealed a decline in Vitamin $\mathrm{C}$ content of all the irradiated samples of the varieties of garden eggs during storage at ambient conditions. [33] similarly reported decrease in Vitamin C content of tomato and orange after 21 days of storage. The significance of storage conditions was well illustrated in the study where Vitamin C content increased in tomatoes stored for 15 days at cool temperatures, but there were losses of $15 \%$ of Vitamin $\mathrm{C}$ during storage at $25{ }^{\circ} \mathrm{C}$ [21]. It has been reported that varietal differences, metabolic changes in plant tissue, and storage conditions have greater impact on Vitamin $\mathrm{C}$ content in fruits and vegetables than irradiation treatment during storage [19, 34]. This might explain the non-uniform decline in Vitamin C content of the samples of variety A and $\mathrm{C}$ compared to variety $\mathrm{B}$ as observed in this study.

\section{Conclusion}

The effect of gamma irradiation (1 - $3 \mathrm{kGy}$ ) on Vitamin C content of the three varieties of garden eggs was not uniform. Whiles there were decreases in Vitamin C content in Solanum torvum, decreases in Solanum aethiopicum L. [GH 8772 and GH 8773] did not have any pattern. Packaging with polythene decreased the content of Vitamin C in fruits of Solanum torvum but not those of Solanum aethiopicum L. [GH 8772 and GH 8773]. Storage period decreased the Vitamin C content of packaged samples of all varieties and in the case of Solanum torvum there was also a clear pattern of decline in Vitamin $\mathrm{C}$ content under unpackaged conditions.

\section{References}

[1] Kashyapa, V., Vinod Kumara S., Collonnierb, C., Fusaric, F. Haicourb, R., Rotinoc, G.L., Sihachakrb, D., and Rajam, M.V. (2002). Biotechnology of Eggplant. Scientia Horticulturae 1846: 1-2.

[2] Barbagallo, R. N., Riggi, E., Avola, G., and Patanè, C. (2012). Biopreservation of 'Birgah' eggplant from Polyphenol Oxidase activity assayed in vitro with onion (Allium cepa L.) by-products. AIDIC Servizi S.r.1., ISSN 1974-9791.

[3] Okon, E. U., Enete, A. A. and Bassey, E. N. (2010). Technical efficiency and its determinants in garden egg (Solanum spp) production in Uyo metropolis, Akwa Ibom State. Special issue 1(4); Urban Agriculture. (Downloaded on: 20/03/2013 at 9:09 pm)

[4] Edijala, J. K., Asagba, S. O., Eriyamremu, E. G. and Atomatofa, U. (2005). Comparative effect of garden egg fruit, oat and apple on serum lipid profile in rats fed on high cholesterol diet. Pakistan Journal of Nutrition 4 (4): $245-249$.

[5] Matsubara, K., Kaneyuki, T., Miyake, T., Mori, M. (2005). Antiangiogenic activity of nasunin, an antioxidant anthocyanin, in eggplant peels. Journal of Agricultural and Food Chemistry 53: $6272-6275$.

[6] Han, S. W., Tae, J., Kim, J. A., Kim, D. K., Seo, G. S., Yun, K. J., Choi, S. C., Kim, T. Y., Nah, Y. H., Lee, Y. M. (2003). The aqueous extract of Solanum melongena inhibits PAR2 agonist-induced inflammation. Clinica Chimica Acta 328: 39 -44 .

[7] Yang, R. Y. (2006). Application of antioxidant activity analytical methods for studies on antioxidant activities of vegetables. Ph.D. Dissertation, Institute of Tropical Agriculture and International Cooperation of National Ping-tung University of Science and Technology, Taiwan.

[8] Raigón, M. D., Prohens, J., Muñoz-Falcón, J. E., and Nuez, F. (2008). Comparison of eggplant landraces and commercial varieties for fruit content of phenolics, minerals, dry matter and protein. Journal of Food Composition and Analysis 21: $370-376$.

[9] Vinson, J. A., Hao, Y., Su, X., Zubik, L. (1998). Phenol antioxidant quantity and quality in foods: vegetables. Journal of Agricultural and Food Chemistry 46: 3630 - 3634.

[10] Stommel, J. R. and Whitaker, B. D. (2003). Phenolic acid content and composition of eggplant fruit in a germplasm core subset. Journal of the American Society of Horticultural Science. 128:704-710. 
[11] Edmonds, J. M. and Chweya, J. A. (1997). Black nightshades. Solanum nigrum L. and related species. Promoting the conservation and use of underutilized and neglected crops. 15. Institute of Plant Genetics and Crop Plant Research, Gatersleben/International Plant Genetic Resources Institute, Rome, Italy; pp 9-20

[12] Jha, S. N. and Matsuoka, T. (2002). Surface stiffness and density of eggplant during storage. Journal of Food Engineering 54: 23 26.

[13] Arvanitoyannis, I. S., Khah, E. M., Cristakou, C. and Bletsos, F. A (2005). Effect of grafting and modified atmosphere packaging on eggplant quality parameters during storage. International Journal of Food Science and Technology 40: 311-322.

[14] Concellón, A., Anón, M. C. and Chaves, A. R. (2007). Effect of low temperature storage on physical and physiological characteristics of eggplant fruit (Solanum melongena L.). Lebensm.-Wiss. Technology 40: 389-396.

[15] Doymaz, Ibrahim and Göl, Esin (2009). Convective drying characteristics of Eggplant slices. Journal of Food Process Engineering 34:1234-1252.

[16] Adu-Gyamfi, A. (2009). Irradiation of fresh fruits and vegetables for improved quality. Ghana Journal of Horticulture, 7:129 -138.

[17] Diehl, J. F. (1995). Safety of Irradiated Foods. Marcel Dekker, New York.

[18] Diehl, J.F., Hasselmann, C. and Kilcast, D. (1991). Regulation of food irradiation in the European Community: Is nutrition an issue? Food Control 2: 212-219.

[19] Kilcast, D. (1994). Effect of irradiation on vitamins. Food Chem 49: $157-164$

[20] Kevers, C., Pincemail, J., Tabert, J., Defraigne, J. O., Dommes, J. (2011) Infuence of cultivar, harvest time, storage conditions, and peeling on the antioxidant capacity and phenolic and ascorbic contents of apples and pears. J. Agr Food Chem 59 911): 6165-6171.

[21] Vinha, A. F., Barreira, S. V. P., Castro, A., Oliviera, M.B.P.P. (2013). Influence of storage conditions on the physicochemical properties, antioxidant activity and microbial flora of different tomato (Lycppersicon esculentum L.) cultivars. J Agr Sci 5 (2): 118-128.

[22] Cianglini, P., Santos, H. L., Daghastanli, K. R. P. and Thedei, G. (2001). Using a classical method of vitamin C quantification as a tool for discussion in its role in the body. Journal of Biochemistry and Molecular Biology Education. 29: 110 - 114.

[23] Eitenmiller, R. R. Ye, L. Landen, W. O. Jr. (2008). Vitamin analysis for the health and food sciences, $2^{\text {nd }}$ ed, CRC,Press.
[24] Fan, X and Sokorai, K.J.B. (2002). Sensorial and chemical quality of gamma-irradiated fresh-cut iceberg lettuce in modified-atmosphere packages. J. Food Prottet. 65:1760-1765.

[25] Zhang, L., Lu, Z. and Wang, H. (2006). Effect of gamma irradiation on microbial growth and sensory quality of fresh-cut lettuce. International Journal of Food Microbiology 106: 348-351.

[26] Maxie, E. C and Sommer, N. F. (1968). Changes in some chemical constituents in irradiated fruits and vegetables. In: INTERNATIONAL ATOMIC ENERGY AGENCY. Preservation of fruit and vegetables by radiation. Vienna, 39-44.

[27] Ramamurthy, M. S., Kamat, A., Kakatkar, A., Ghardge, N., Bhushan, B, Alur, M. (2004). Improvement of shelf-life and microbiological quality of minimally processed refrigerated capsicum by gamma irradiation. Int. J. Food Sci. Nutr. 55(4): 291-299.

[28] Hajare S. sN, Dhokane V. S, Shashidhar R and Saroj S (2006). Radiation Processing of Minimally Processed Pineapple (Ananas cosmosus Merr.): Effect on Nutritional and Sensory Quality. Journal of Food Science. 71(6): S501.

[29] Alabadan, B. A., Sunmonu, M. O. and Sunmonu, T. O. ( 2008) Effect of packaging materials on some nutritional qualities of fruits and vegetables stored in a passive evaporative cooler. As. J. Food-Ind, 1(03), 184-196).

[30] Hussain, A., Odumeru, J. A., Ayanbadejo, T., Faulkner, H., McNab, W. B., Hager, H. and Szijarto, L. (2000) Effect of processing and packaging on vitamin $\mathrm{c}$ and $\beta$-carotene content of ready-to-use (RTU). 33 (2): 131-136.

[31] Rickman, C., Barret, D. M., and Bruhn, M. (2007). Nutritional comparison of fresh, frozen and canned fruits and vegetables. Part I. Vitamins C and B and phenolic compounds. Journal of Science in Food and Agriculture. 87:930-944.

[32] Lee, S.K. and Kader, A.A. 2000. Preharvest and postharvest factors influencing vitamin $\mathrm{C}$ content of horticultural crops. Postharvest Biology Technology, 20, 207-220.

[33] Abah Idah, A. P., Musa, J. J., and Olaleye, S. T. (2010). Effect of temperature and drying time on some nutritional quality parameters of dried tomatoes. Australia Journal of Technology $14(1): 25-32$.

[34] Thomas, P. and Janave, M. T. (1975). Effects of gamma irradiation and storage temperature on carotenoids and ascorbic acid content of mangoes on ripening. Journal of Science and Food Agriculture 26, 1503-1512. 